Univerzitet u Beogradu
Poljoprivredni fakultet
Institut za poljoprivrednu tehniku
Naučni časopis
POLJOPRIVREDNA TEHNIKA
Godina XLIII
Broj 4, 2018.
Strane: $1-7$

\title{
MUTUAL IMPACT OF DIFFERENT PARAMETERS IN YIELD MONITORING
}

\author{
Dragan Marković ${ }^{1}$, Vojislav Simonović*1, Nevena Tasić ${ }^{1}$, \\ Ivana Medojević ${ }^{1}$ Aleksandra Joksimović ${ }^{1}$ \\ ${ }^{1}$ Univesity of Belgrade, Faculty of Mechanical Engineering
}

\begin{abstract}
When measuring and analyzing site-specific yield known as the yield monitoring within a wider cycle of precise agriculture, about 30 parameters are measured from inertia for mapping yields. The most important parameters with the default three parameters that define the location (latitude, longitude and elevation) are mass grain yield and grain moisture. In addition to this data during the yield monitoring, the temperature of the grain, speed of the combine and delution of precision (DOP) were also observed in this paper. By simple statistical testing of the correlation between these parameters, the level of mutual influence was determined, among other things, the degree of influence of all mentioned and observed parameters on yield, in response to the research question whether the yield affects another parameter other than the location and physical and chemical properties of the land at that location . A different degree of influence was determined, but no significant additional impact on the yield was calculated by measuring and measuring the measurement itself.

For the monitoring of the yield of seed wheat harvesting on the "Mladost" PKB, Tabla 2, the Class Lexion 450 harvester with an upgraded system for monitoring the AGL Technology manufacturer was used. For the statistical analysis, the parametric method of correlation within the software package SPSS Statistics v.21 was used.
\end{abstract}

Key words: correlation, seed wheat, yield

\footnotetext{
* Kontakt autor. E-mail adresa: vsimonovic@mas.bg.ac.rs

TR35043 Istraživanje i razvoj opreme i sistema za industrijsku proizvodnju, skladištenje i preradu voća i povrća.
} 


\section{INTRODUCE}

In the beginning, agronomy was done without use of any system. With growth of population, the need for food rise, and with it the need for more intensive use of land, namely planed crop change in time and space. Basic characteristic of all systems is maximal usage of vegetational factors for getting high and stable yield, while keeping field fertile [6]. The largest part of the production of winter wheat in Serbia is related to the agro-technology of larger investments in this production, with varieties created for such conditions. Economical need demands reduced investment in production, moving from convectional to rational reduced investments systems [5]. Variation in the yield of winter wheat is very expressive, depending on variation of average monthly air temperature and monthly precipitation in examined period. Bad meteorological conditions have particularly negative impact on the grain yield in the monoculture. Insufficient precipitation, especially in first two years of testing, is regularly followed with their unfavorable schedule. They were characterized by very small amounts of precipitation in April, May and June. [3,7].

Most important crop for bread making, basic food item in whole world is wheat. It is ranked among the most important plants that man cultivates. It is produced in the whole word in areas between 16 to 60 degrees north, and 20 to 50 degrees south latitude and at altitudes up to $3000 \mathrm{~m}$, wherever there are conditions for its production. In order to exploit its economic potential it is necessary to produce quality seed. There is no high yield without quality seed [11]. In this paper large number of parameters is being analyzed during harvest from the aspect of their mutual influence, with extra attention to the yield and moisture of the grain.

Reported accuracy of continuous yield monitoring depends on the type and brand of yield monitor, calibration regime, flow rate and conditions at harvest. Accuracy is ranges from 93 to $99.5 \%$ [1,2,4]. Gradual and sudden speed changes affect the accuracy of yield measurements. Arslan and Colvin [1] showed that average error rates at a constant speed were $3 \%$, but varying speed between 8 and $11 \mathrm{~km} / \mathrm{h}$ increased the average error to $5.2 \%$. When combine speed varied gradually, depending on yield variation, the measurement error almost doubled. Larger errors are observed when ground speed changes abruptly.

\section{MATERIAL AND METHOD}

Combine harvesting that was used in this study was equipped with header width of 6 $\mathrm{m}$. Sensor for measuring the mass flow of grain set on top of the clean grain elevator, a sensor for measuring the moisture content is placed in the middle of the clean grain elevator, Figure 1 mass sensor measures the impact force exerted by the dumped grain elevators with blades falling on the impact plate. 

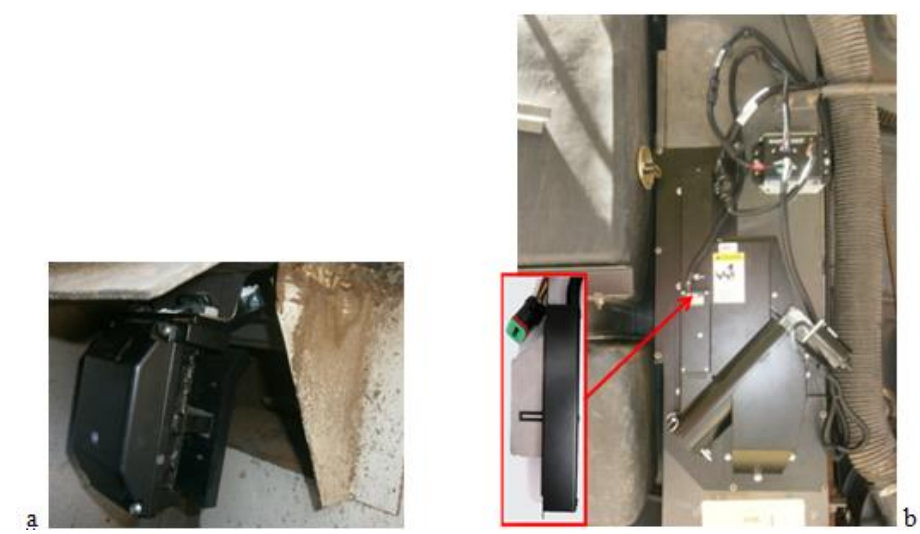

Figure 1. a- Gape between elevator and auger for clear grain and impact plate of mass flow sensor with modul (view from grain tank) and $b$ - grain moisture sensor [10]

On the basis of this force, as well known to the width of the developer, the speed of movement and the speed of the elevator to the grain, as well as the percent of moisture, calculated on the weight of dry yield of grain. The effect of vibration harvester was eliminated the previous calibration mass sensor [9]. It is also pre-calibrated sensor and moisture content. System for the measurement of the yield is configured to successively records data on every two seconds. This is the time interval measurement, which was constant. Changing only the distance traveled during this time which is dependent on the speed of the combine and also was scored for each time interval of two seconds. If the recording interval in the range of 1-3 s, generate very large data sets, even for small fields [8]. The system for measuring grain yield is adjusted to successively record data at 2 -second intervals. This was a constant time interval of measuring. The only parameter that changed was the distance travelled during that time, depending on the combine speed and was also recorded at 2 -second intervals. The recording of measurements at 1-3 second intervals generates large datasets, even for small fields [8, 12].

Mass flow monitoring started 10 seconds after the adapter with a cutterbar was lowered for working position, and finished 10 seconds on lifting the cutterbar. Practically, there was a time shift for mass flow monitoring, consequently the yield, actually amounting to 10 seconds and representing transport time delay, i.e. the time needed for crop grain to travel through combine technological devices from the time moment of cutting to the time moment of grain striking against the impact plate of the mass flow sensor. Various factors such as combine separator design and settings and monitoring systems can affect the data gathering process so that the time shift should be adjusted. Without this adjustment, the grain flow and moisture values cannot be properly coordinated with location and area information to deliver data that accurately represent that location [1]. 


\section{RESULTS AND DISCUSSION}

Site yield of dry grain seed wheat on this field per display distribution, is given in Fig. 2 Such groupings yield of dry grain can be defined organizational zone explored part of the plot. Harvesting the plot is done three to five combines, but only one was equipped with tracking devices yield.

Correlation describes the intensity and direction of the linear relationship between the two variables. With the IBM SPSS Statistics v.21 software, it is possible to calculate the Spirman's correlation coefficient $r_{0}$. This coefficient is suitable for ordinal quantities or ranked quantities.

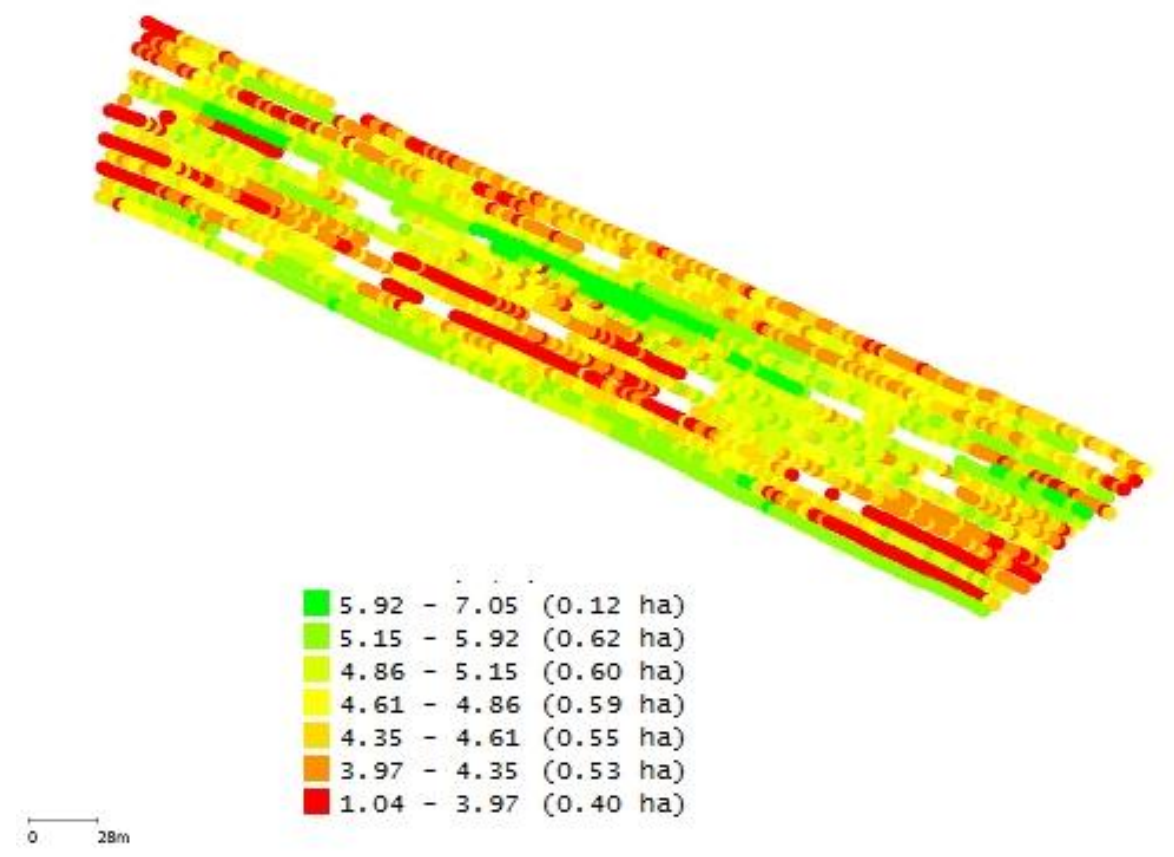

Figure 2. Site-specific yield on map

The correlation value can be between 0 and 1 . Various authors give different interpretations, however, Cohen gives the following guidelines for the correlation size: a small correlation of $0,10<r_{0}<0,29$, a mean correlation of $0,30<r_{0}<0,49$, a large correlation of $0,50<r_{0}<1$. These guidelines apply regardless of whether there is a negative sign in front of the coefficient $r_{0}$. A negative sign indicates its direction, not the magnitude [3].

Table 1 shows a matrix view of the relationship between the individual variables that were the subject of research in the context of yield monitoring. These relationships in terms of correlation are shown by means of the Spirman coefficient with an appropriate statistical significance for each pair of 6 mutually crossed variables. 
Table 1. Results of Spearman's Correlations for differnet cases by Correlation Coefficient and Sig. (2-tailed) in the brakets: $a_{1}-$ Elevation, $a_{2}-$ PDOP, $a_{3}-$ Moisture,

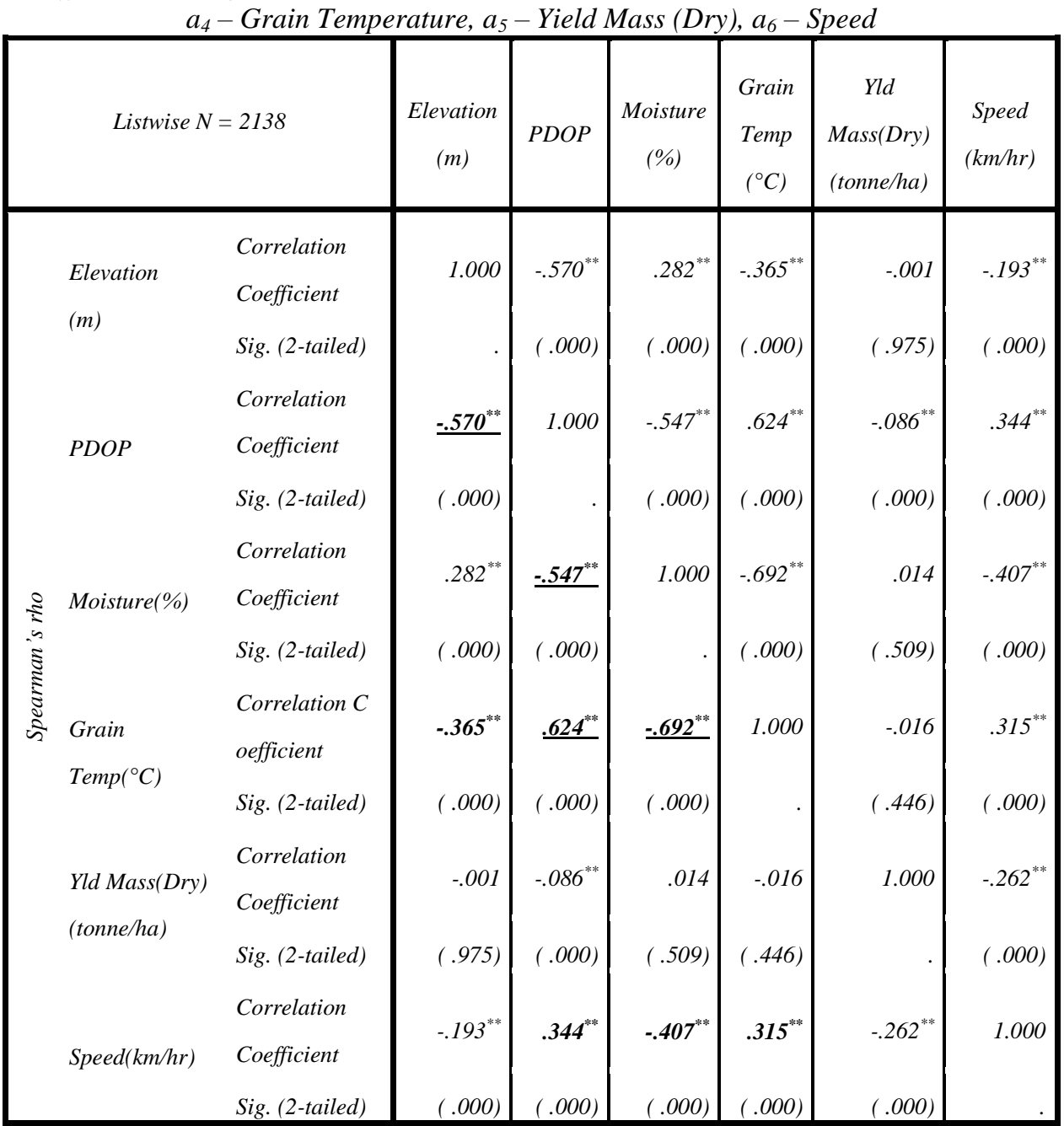

**. Correlation is significant at the 0.01 level (2-tailed).

The strength of the correlation, or how many percentages of the variance of one variable, explains the other variables are defined in accordance with Cohen's division. In that sense, it is particularly important to emphasize those relations between variables where $r_{0}>0,50$, as this suggests a large correlation. Such correlations according to the data in Table 1 have a total of four (underlined bold values).

The number of relations between variables where 0,50>r $>0,30$, (mean correlation) is four (only bolded values). 


\section{CONCLUSION}

Among all the parameters observed, the only mass grain yield is not significantly correlated with other parameters. Only the correlation $r_{0}\left(a_{5}, a_{6}\right)=-0,262$ is distinguished by value. This suggests the conclusion that the mass yield affects $6 \%$ of the variation of the speed of the combine in the opposite direction, or that the operator of the combine slows the combine with the yield increase. PDOP, or precision of positioning, has a very significant correlation with elevation, speed, temperature and humidity of the grain. Thus, the increase in imprecision manifested by the higher PDOP value most affects the measured temperature. Temperature and humidity are measured by the same sensor within the Elevator Mounting Unit (EMU), so it is suggested that according to $r_{0}\left(a_{3}, a_{4}\right)=-0,692$, even $49 \%$ of the variation of one variable depends on the variance of the second variable.

\section{LITERATURA}

[1] Arslan, S., \& Colvin, T. S. (2002). An evaluation of the response of yield monitors and combines to varying yields. Precision Agriculture, 3, 107-122.

[2] Birrell, S. J., Sudduth, K. A., \& Borgelt, S. C. (1996). Comparison of sensors and techniques for crop yield mapping. Computers and Electronics in Agriculture, 14(2-3), 215-233

[3] Cohen, J.W. 1988. Statistical power analysis for the behavioral sciences (2nd edn). Hillsdale, NJ: Lawrence Erlbaum Associates, pp. 79-81.

[4] Fulton, J. P., Sobolik, C. J., Shearer, S. A., Higgins, S. F., \& Burks, T. F. (2009). Grain yield monitor flow sensor accuracy for simulated varying field slopes. Applied Engineering in Agriculture, 25(1), 15-21.

[5] Kovačević, D., Dolijanović, Ž., Jovanović, Ž., Milić, V. 2005. Uticaj tehnologije gajenja na prinos ozime pšenice. Poljoprivredna tehnika, Vol. 1, 27-32.

[6] Kovačević, D., Dolijanović, Ž., Oljača, S., Milić, V. 2007. Organska proizvodnja alternativnih vrsta ozime pšenice. Poljoprivredna tehnika, Vol. 4, 39-45.

[7] Kovačević, D., Oljača, S., Dolijanović, Ž., Oljača, M. 2008. Uticaj savremenih sistema obrade zemljišta na prinos važnijih ratarskih useva. Poljoprivredna tehnika, Vol. 2, 73-80.

[8] Lyle, G., Bryan, A., \& Ostendorf, B. 2014. Post-processing methods to eliminate erroneous grain yield measurements: review and directions for future development. Precision Agriculture, 15, 377-402.

[9] Simikić, M., Savin, L.,Tomić, M., Prokeš, B., Mačvanin N., Ivanišević I. 2013. Intensity of vibrations felt by combine harvester driver, Traktori i samohodne poljoprivredne mašine, 18 (5), 56-62.

[10] Simonović, V., Marković, D., Jelena, Ilić., Ivana Marković. 2014. Effect of extreme sitespecifific value yield at the descriptive statistical indicators. Tractors and power machines, 19 (2), 101-108.

[11] Yang, Y., Ding, J., Zhang, Y., Wu, J., Zhang, J., Pan, X., Gao, C., Wang, Y., He, F. 2018. Effects of tillage and mulching measures on soil moisture and temperature, photosynthetic characteristics and yield of winter wheat. Agricultural Water Management, 201: 299-308. 
[12] Zhang, C., Liu, J., Shang, J., Cai, H. 2018. Capability of crop water content for revealing variability of winter wheat grain yield and soil moisture under limited irrigation. Science of the Total Environment, 631-632, 677-687.

\title{
MEĐUSOBNI UTICAJ RAZLIČITIH PARAMETARA PRI MONITORINGU PRINOSA
}

\author{
Dragan Marković ${ }^{1}$, Vojislav Simonović ${ }^{1}$, Nevena Tasić ${ }^{1}$, \\ Ivana Medojević $^{1}$ Aleksandra Joksimović ${ }^{1}$ \\ ${ }^{1}$ Univerzitet u Beogradu, Mašinski fakultet, \\ Katedra za poljoprivredno mašinstvo
}

Sažetak: Pri merenju i analizi lokacijski specifičnog prinosa poznatijeg kao monitoring prinosa u okviru šireg ciklusa precizne poljoprivrede meri se oko 30 parametara od interesa za mapiranje prinosa i šire. Najvažniji parametri uz podrazumevana tri parametra koja definišu lokaciju (latituda, longituda i elevacija) su maseni prinos zrna i vlažnost zrna.

$\mathrm{Uz}$ ove podatke tokom monitoringa prinosa $\mathrm{u}$ ovom radu posmatrani su i temperatura zrna, brzina kretanja kombajna i odstupanje preciznosti lociranja (DOP). Jednostavnim statističkim testiranjem korelacije između ovih parametara utvrđen je nivo međusobnog uticaja, između ostalog i stepen uticaja svih navedenih i posmatranih parametara na prinos, kao odgovor na istraživačko pitanje da li na prinos utiče još neki parametar osim lokacije i fizičko-hemijskih osobina zemljišta na toj lokaciji. Utvrđen je različit stepen uticajnosti, ali nije otkriven ni jedan značajan dodatni uticaj na prinos izračunat posredstvom merenja i makon samog merenja.

Za monitoring prinosa pri žetvi semenske pšenice na imanju „Mladost“ PKB, Tabla 2, korišćen je kombajn Class Lexion 450 sa nadograđenim sistemom za monitoring AGL Technology proizvođača. Za statističku analizu korišćena je parametarska metoda korelacije u okviru softverskog paketa SPSS Statistics v.21.

Ključne reči: korelacija, semenska pšenica, prinos

Prijavljen:

01.10.2018.

Ispravljen: $\quad 10.10 .2018$

Prihvaćen: $\quad 03.11 .2018$. 